Vol. 4, No. 02; 2021

ISSN: 2581-4664

\title{
THE EFFECT OF TRAINING AND TALENT MANAGEMENT ON ORGANIZATIONAL COMMITMENT AND ITS IMPLICATIONS ON EMPLOYEE PERFORMANCE AT CONSTRUCTION SERVICE COMPANY IN BANDA ACEH CITY
}

\author{
Ahmad Haeqal Asri, Mukhlis and Said Musnadi \\ Department of Management, UniversitasSyiah Kuala, Indonesia \\ http://doi.org/10.35409/IJBMER.2021.3318
}

\begin{abstract}
This study aims to measure the effect of training and talent management on organizational commitment and its implications for employee performance. This research was conducted at a construction service company in Banda Aceh city, Indonesia. 493 employees became the population of this research. Slovin formula was used so 221 respondents were determined as the sample. Researchers used Structural Equation Modeling (SEM) to test the effects between variables. The results of the study found that Training Affects Employee Performance, Talent Management Affects Employee Performance, Organizational Commitment Affects Employee Performance, Training Affects Organizational Commitment, Talent Management Affects Organizational Commitment, Training Affects Employee Performance Through Organizational Commitment, and Talent Management Affects Employee Performance Trough Organizational Commitment. The findings also show that organizational commitment serves as a partial mediator. All these findings reinforce previous theories of causality and are combined into one unified model as a model for improving employee performance for construction companies located in Banda Aceh. By increasing training and talent management, it is proven that it can improve organizational commitment and employee performance. Future researchers are expected to develop this tested model by adding research variables such as human capital and company performance.
\end{abstract}

Keyword: Training, Talent Management, Organizational Commitment, Employee Performance.

\section{INTRODUCTION}

In Banda Aceh city, there are many companies engaged in construction services compared to the number of construction service companies in other cities/districts in Aceh Province. The number of construction service companies in Aceh reaches 2048 companies, 340 or 16.60 percent of them live in the city of Banda Aceh. Construction service companies in Banda Aceh are dominated by small companies with a total of 71.18 percent, while construction service companies with a medium classification (M1 and M2) are only 27.06 percent. Construction service companies with a large classification only 1.18 percent. The smaller the company classification, the less it is found to provide training for the human resources of the company.

As is the case with various companies and other business fields, companies engaged in the provision of construction services in reality experience various problems and obstacles in the 


\section{International Journal of Business Management and Economic Review}

Vol. 4, No. 02; 2021

ISSN: 2581-4664

human resources aspect, especially when companies compete with similar companies from outside the region with a very high risk of business failure. In addition, construction service companies in Aceh are currently facing various complex problems, especially with the entry of construction service companies from outside that also participate in tenders for APBA (Aceh Revenue and Expenditure Budget) projects, where Aceh gets a share from the fund oil and gas resulting competition between local contractors and outside contractor who want to win the APBA tender. As a result, there are many construction service companies in Aceh, especially in Banda Aceh have not received projects or won tenders that have been carried out by the Aceh Government and the Banda Aceh government, thus the survival of construction service companies in Banda Aceh has become unclear.

Based on the initial survey it can be explained that the performance of the construction service company employees is not good, this can be seen from the average value which is only 3.41 on the Likert scale. This indicates that the performance is still relatively low. According to the admissions of several company managers and the Chairperson of the Banda Aceh Construction Service Entrepreneurs Association (Gapensi), they admitted that they rarely did the trainingeven though the skills of their employees were still very low.

Training is given in construction service companies in Banda Aceh at this time, aimed at closingthe "gap" between the expected skills and the demand for construction service and to improve the efficiency and effectiveness in achieving goals, especially to win the auction, doing contract jobs from third parties, and carrying out routine corporate administrative tasks. In line with this, training for them is also aimed at preparing employees to have competencies in order to achieve company goals that have been set following the vision and mission. To realizethis vision, only some companies make it into work programs, as well as "action plans", which become a "learning and growth" framework that contains programs for enhancing employee competencies through providing training according to their abilities. According to (Hasibuan, 2016), training is an effort to increase the knowledge and skills of an employee in a company in carrying out a certain job. This study looks more specifically at employee productivity training, which is currently perceived as an unsolved obstacle.

Besides the scarcity of trained and skilled human resources in construction service companies, a talent management application in construction service companies in Banda Aceh is still limited to company employees. The existence of the talent management variable is recognized as important by company leaders, but it has not been resolved due to the limited quality of human resources. Several companies, especially from the middle and large classifications in Banda Aceh, have implemented talent management in their companies. Some of them use experts to manage talent in their company. In general, talented human resources are still limited to construction service companies in Banda Aceh. This happens because of the low employee performance or productivity as well as overall company performance.

One of the causes of low employee productivity or performance is the low organizational commitment of employees to their organization. Organizational commitment behavior is voluntary (OCB) and is not an act that is forced to promote organizational interests as a form of performance-based satisfaction, and not formally determined or directly related to the formal reward system (Chairy, 2011). However, productivity that exceeds what should be largely determined by whether or not the employee's commitment to the organization is strong or not (Smith, Organ, \& Near, 1983) In (Kusumawardhani, 2010). The results of research conducted by 


\section{International Journal of Business Management and Economic Review}

Vol. 4, No. 02; 2021

ISSN: 2581-4664

(Alqudah, Osman, \& Alquda, 2014) stated that an increase in employee performance in an organization is strongly influenced by the organizational commitment of the employee. This indicates that an increase in employee performance can be influenced by the presence of organizational commitment possessed by the employees. The phenomenon that occurs in construction service companies in Banda Aceh City shows that employee performance is also influenced by the low organizational commitment of employees, especially the commitment to carry out their duties and responsibilities properly and responsibly.

Meanwhile, there are also other research results with the same variables that have less influence on individual employee performance. The results of research conducted by (Hernaus, Bach, \& Vuksic, 2012) stated that the organizational commitment in an organization is only influenced by several factors, including the existence of knowledge management possessed by employees, organizational learning provided by the organization to employees and job satisfaction felt by employees in carrying out their duties and functions. Research conducted by (Azis, Djalil, Bahri, \& Sunar, 2017) showed that the organizational commitment of employees has an influence in improving employee performance. Several research findings with varied results encourage researchers to conduct new research related to variables of training, talent management, organizational commitment and employee performance at construction service companies in Banda Aceh which are increasingly competitive and difficult to predict. Based on the background, the authors are interested in focusing and examining more deeply in the form of a final work entitled: "The Effect of Training and Talent Management on Organizational Commitment and Its Implications on Employee Performance at Construction Service Companies in Banda Aceh".

\section{LITERATURE REVIEW}

\subsection{Employee Performance}

There are many references that can be used to assess employee performance. (Mathis \& Jackson, 2019) stated that the concept of performance comes from performance. Performance can be examined individually and organizational performance. (Riduwan \& Kuncoro, 2014) defined individual performance as individual work performance which is regulated based on the standards or criteria set by an organization. According to (Munandar, Musnadi, \& Sulaiman, 2019), performance appraisal is a process of assessing the personality,work behavior and performance of an employee who is believed to support his productivity, which is used as a consideration in deciding what to do against him at work. According to Larry D. Stout in (Tangkilisan, 2005), measuring or evaluating organizational performance is the process of recording and measuring the achievement towards a mission through the results. According to (Mathis \& Jackson, 2019) several factors affect employee performance improvement, including:

a. Talent management: The process undertaken to ensure that key positions in our company can be filled internally by forming a group of talent development centers consisting of a group of highly qualified and qualified company human resources (talent pool).

b. Training: A conscious effort made by educators through guidance, teaching to help students experience the process of self-humanity towards achieving a mature, moral personality

c. Job satisfaction

d. Organizational commitment: the form of work commitment that appears is not only passive loyalty, but also involves active relationships. Besides the variables above, there are still 


\section{International Journal of Business Management and Economic Review}

Vol. 4, No. 02; 2021

ISSN: 2581-4664

quite a lot of variables that influence employee performance such as work environment, education level, compensation, leadership style, teamwork and so on which were not examined in this study. For the purposes of measuring variations in employee performance at construction service companies in Banda Aceh, it is referred to the opinion of Mathis and Jackson (2013),with employee performance indicators consisting of:

1. Work quality

2. Quantity

3. Punctuality

4. Effectiveness

5. Independence

6. Work Commitment

\subsection{Organizational Commitment}

A strong organizational commitment by individuals will motivate employees to achieve organizational goals that are aligned with organizational goals and interests (Mowday, Porter, \& Steers, 2013) and will have a positive impact for the good of the organization (Angle \& Perry, 1981), (Mowday, Steers, \& Porter, 1979)in (Coryanata, 2014). High commitment makes people care about the fate of the organization and strive to improve its direction. (Coryanata, 2014) defined organizational commitment as the inner driving force of a person to do something to support the success of the organization in accordance with its goals and prioritizes the interests of the organization above its own. Commitment will make the organization more productive (Luthans, 2006) in (Coryanata, 2014). According to (Mathis \& Jackson, 2019) organizational commitment is a form of work commitment that appears not only as passive loyalty, but also involves active relationships. Many factors influence organizational commitment. Furthermore, (Meyer \& Allen, 2004) clearly defines a commitment to the organization as the relative strength of an individual in determining his participation in the organization. This attitude can be characterized by three things, namely:

a. Strong belief and acceptance of the values and goals of the organization, or have confidence in the existence of the organization and the goals to be achieved by the organization.

b. The willingness of employees to strive on behalf of the organization, meaning that employeesare willing to make sacrifices in improving organizational performance

c. A strong desire to maintain membership in the organization, means employees have a strong desire to support organizational performance.

Many factors affect organizational commitment that affect individual performance and the performance of an organization. (Robbins \& Judge, 2012), stated that the variable organizational commitment of an employee is influenced by several factors, including:

1. Knowledge Management

2. Learning Organization

3. Job Satisfaction

To measure the effect of organizational commitment, it can be seen in the indicators. Indicators of organizational commitment include (1) Training, (2) Work standards, (3) Equipment and technology, (4) Level of expectation (5) a productive work team. Then other indicators according 


\section{International Journal of Business Management and Economic Review}

Vol. 4, No. 02; 2021

ISSN: 2581-4664

to Steers and Porter (2013) are (1) dedication, (2) improving performance, (3) high willingness and (4) work targets. However, in this study the authors are more likely to use the opinion of Mathis and Jackson (2011: 84), because it is in accordance with the circumstances in the construction service company.

\subsection{Training}

Training is a short-term educational process using certain systematic and organized procedures. (Notoatmojo, 2012) described the training as an effort to develop people as individuals and to encourage them to be more confident and capable in life and work. Basically, training can also be interpreted as a form of acquisition of knowledge, skills, and attitudes that enable humans to achieve individual and organizational goals today and in the future.

According to the constitution, number 43 year 1999 part six concerning Education and Training (Article 31 Paragraph 1), the objectives of training for a civil servant are:

a. Increase knowledge, experience, skills and attitudes to be able to carry out official duties in a professional manner, based on the personality and ethics of civil servants in accordance with the needs of the agency.

b. The establishment of an apparatus capable of acting as reformers and the glue of national unity and integrity.

c. Strengthening the attitude and spirit of service-oriented services, protection and community empowerment.

d. The creation of a common vision and dynamic thinking in fulfilling the general objectives of public administration and development for good governance

Training indicators according to (Mangkunegara, 2013) are as follows: 1.Training Objectives 2.Theory 3.Methods Used 4.Qualification of Participants For employees or the performance of a private business or company, the aim of the training is toimprove the quality of human resources which has an impact on the overall performance of the company.

\subsection{Talent Management}

Talent refers to the ability of staff to produce good performance continuously, bringing as life capital (Yunus, Iis, Adam, \& Sofyan, 2020). According to (Pella \& Inayati, 2011), talent management is a process that allows companies to prepare future leaders and key positions that support the company's core competencies (unique skills and high strategic value). (Yarnall, 2011) mentioned that talent management involves selecting and developing employees who are considered talented in a company therefore they can create a group of people whose talents can be developed to become investments in the company. This group of talented people is known as a talent pool.

The application of talent management in large companies around the world has shown its ability to provide benefits and value given the sustainability of the company, especially in employee management. There are many well-known and conscientious companies in Indonesia that have implemented talent management in their companies. Some of these companies use experts to manage talent. In this study, researchers used the dimensions of talent management according to (Barkhuizen, Mogwere, \& Schutte, 2014), namely: 1) Talent acquisition, which is the activity of looking for, attracting, obtaining, evaluating and recruiting prospective employees 


\section{International Journal of Business Management and Economic Review}

Vol. 4, No. 02; 2021

ISSN: 2581-4664

to fill the positions/roles needed. Now and in the future. 2) Talent development, namely talent development that can contribute to the success and growth of the company. 3) Talent retention company strategy to retain talent and ensure high loyalty from every talented employee to the company.

\subsection{Research Hypothesis}

From the literature can be built the hypotheses to be a research model as follows.

H1 : Training Affects Employee Performance

$\mathrm{H} 2$ : Talent Management Affects Employee Performance

H3 : Organizational Commitment Affects Employee Performance

H4 : Traning Affects Organizational Commitment

H5 : Talent Management Affects Organizational Commitment

H6 : Training Affects Employee Performance Through Organizational Commitment

H7 : Talent Management Affects Employee Performance Trough Organizational Commitment

\section{RESEARCH METHOD}

\subsection{Population and Sample}

The population in this study was all employees of construction service companies in Banda Aceh, as many as 493 people. The amount of sample was determined using the Slovin formula, provided as many as 221 respondents.

\subsection{Data Collection}

The data collected were as follows.

a. Primary data, collected directly through a questionnaire consisting of question items distributed to employees of construction service companies in Banda Aceh

b. Secondary data, obtained from the documentation of construction service companies in the city of Banda Aceh

\subsection{Data Analysis Method}

The data analyzed using The Structural Equation Modeling (SEM). (Hair, Hult, Ringle, \& Sarstedt, 2016) explain that the SEM equation model is a set of statistical techniques that allow testing a series of relatively "complicated" relationships simultaneously.

\section{RESULT}

\subsection{Research Result}

The structural model analysis that explains the effect of talent management and training on organizational commitment and its implications for employee performance can be seen in thefollowing diagram: 


\section{International Journal of Business Management and Economic Review}

Vol. 4, No. 02; 2021

ISSN: 2581-4664

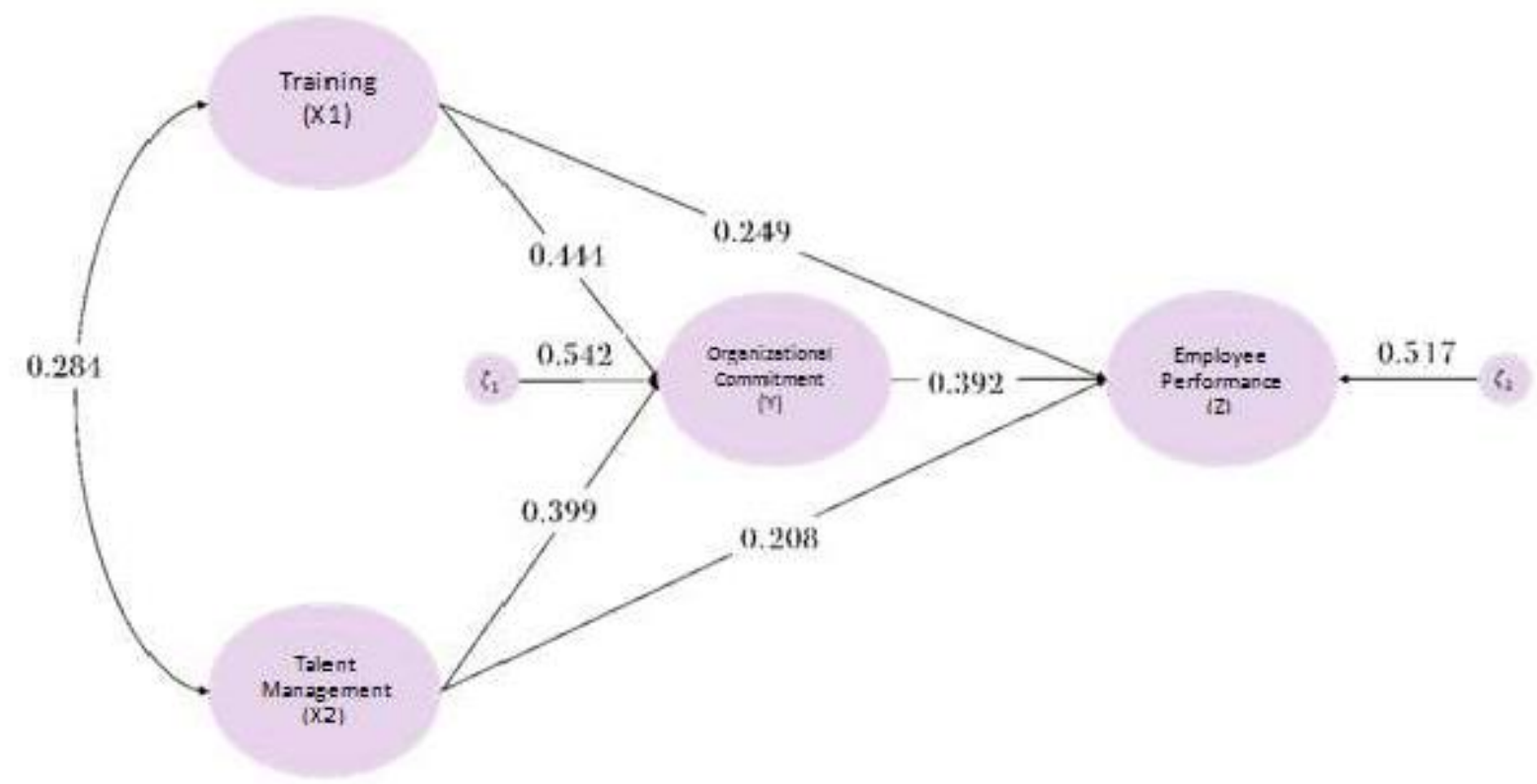

Figure 1. Structural Equation Model (SEM) Test Results

The structural model of Talent Management and Training towards organizational commitmentand its implications for employee performance can be written in the following equation:

Organizational commitment $=0,444 \times$ Training $+0,399 \times$ Talent Management

Employee performance $=0,249 \times$ Training $+0,208 \times$ Talent Management $+0,392 \mathrm{x}$ Organizational commitment

\section{Direct Effect}

Structure 1 : The Effect of Training, Talent Management, and Organizational Commitment to Employee Performance

The results of the analysis of training variables, talent management and organizational commitment to employee performance are shown in the following table

Table 1. Test Result of the direct influence of Training, Talent management and Organizational Commitment on performance

\begin{tabular}{|l|c|c|c|}
\hline \multicolumn{1}{|c|}{ Effect } & Coefficient & -value & $\mathrm{P}(>\mathbf{z})$ \\
\hline Training $\rightarrow$ Employee Performance & 0.249 & 2.370 & 0.018 \\
\hline Talent Management $\rightarrow$ Employee Performance & 0.208 & 3.085 & 0.002 \\
\hline Organizational Commitment $\rightarrow$ Employee Performance & 0.392 & 3.427 & 0.001 \\
\hline
\end{tabular}




\section{International Journal of Business Management and Economic Review}

Vol. 4, No. 02; 2021

H1 : The Effect of Training on Employee Performance

The training was found to have a positive and significant effect on employee performance. The magnitude of the influence of training on organizational performance is 0.249 standard deviationwith a $\mathrm{z}$ value of 2.370 and $\mathrm{p}$-value of 0.018 . A p-value less than 0.05 indicates having a significant effect. The positive effect shows that improvements in training will encourage an increase in employee performance. The effect given is smaller than the effect of training on organizational commitment because the process of improving employee performance requires organizational commitment as a mediator.

H2: The Effect of Talent Management on Employee Performance

The results showed that there was a positive and significant influence of the talent managementvariable on employee performance. The amount of direct influence of the talent management variable on the Employee Performance of construction service companies in Banda Aceh is 0.208 with a $\mathrm{z}$ value of 3.085 and p.value 0.002 . The $\mathrm{p}$-value less than 0.05 gives a significanteffect. The direct effect of talent management variable is lower than training on employee performance. This shows that training is the most dominant variable in improving the performance of employees in construction service companies.

\section{H3 : The Effect of Organizational Commitment on Employee Performance}

The study found that the variable organizational commitment was the variable with the greatestinfluence on employee performance. The hypothesis testing result found that there was a positive and significant effect of organizational commitment on employee performance. The results of the calculation show that the magnitude of the influence of organizational commitment on employee performance was 0.392 with a $\mathrm{z}$ value of 3427 and a p-value of 0.000 . The $\mathrm{p}$-value less than 0.05 indicates a significant effect. These results indicate a closerelationship between organizational commitment and employee performance.

\section{Structure 2 : The Effect of Training and Talent Management on Organizational Commitment}

The explanation of the effect of Talent Management and Training on organizational commitmentis as follows:

Table 2. Test Result of The Direct Influence of Talent Management and Training on organizational commitment

\begin{tabular}{|l|c|c|c|}
\hline \multicolumn{1}{|c|}{ Effect } & Coefficient & $z$-value & $\mathrm{P}(>\mid \mathrm{z})$ \\
\hline Training $\rightarrow$ Organizational Commitment & 0.444 & 5.183 & 0.000 \\
\hline $\begin{array}{l}\text { Talent Management } \rightarrow \text { Organizational } \\
\text { Commitment }\end{array}$ & 0.399 & 5.162 & 0.000 \\
\hline
\end{tabular}




\section{International Journal of Business Management and Economic Review}

Vol. 4, No. 02; 2021

\section{H4 : The Effect of Training on Organizational Commitment}

Research hypothesis testing found that there was a positive and significant effect of the training variable on organizational commitment. The direct effect of the training variable is 0.444 with a $\mathrm{z}$-value of 5.182 and a $\mathrm{p}$-value of 0.000 . The p-value less than 0.05 indicates a statistically significant effect. The positive influence shows that the better the training is felt by employees, the better their performance will be.

\section{H5 : The Effect of Talent Management on Organizational Commitment}

Research proves that there is a positive and significant influence of talent management variable on organizational commitment. The magnitude of the influence is 0.399 with a $\mathrm{z}$ value of 5.162 and a p-value of 0.0001 . A p-value less than 0.05 indicates a statistically significant effect. The results show that better talent management will increase organizational commitment, but the increase in organizational commitment is more influenced by training than by talent management. In implementing talent management, construction service companies must pay attention to the process of employee recruitment and training.

\section{Indirect Effect}

H6 : The Indirect Effect of Training on Employee Performance through Organizational Commitment

After proving the direct effect hypothesis, the following is an analysis of the indirect effect of training on employee performance through organizational commitment. The result shows that the indirect effect of training variable on employee performance through organizational commitment is 0.174 .

Table 3 Test Result of The Indirect Effect of Training on Employee Performance through Organizational Commitment

\begin{tabular}{|l|c|c|c|}
\hline \multicolumn{1}{|c|}{ Effect } & Coefficient & $\mathrm{z}$-value & $\mathrm{P}(>\mathbf{z} \mid)$ \\
\hline $\begin{array}{l}\text { Training } \rightarrow \text { Organizational } \\
\text { Commitment } \rightarrow \text { Employee Performance }\end{array}$ & 0.174 & 3.312 & 0.001 \\
\hline
\end{tabular}

The hypothesis testing result reveals that the indirect effect of training on employee performance through organizational commitment has a p-value less than 0.050 so that the null hypothesisis rejected, which means that there is an indirect effect of the training variable on employee performance through organizational commitment. Thus, it can be concluded that the variable organizational commitment is a mediating variable for the training variable.

H7 : The Indirect Effect of Talent Management on Employee Performance through Organizational Commitment

The analysis result using structural equation modeling (SEM) describes that the indirect effect ofthe talent management variable on employee performance is 0.157 . 


\section{International Journal of Business Management and Economic Review}

Vol. 4, No. 02; 2021

ISSN: 2581-4664

Table 4. Test Result of the indirect effect of talent management on employee performance through organizational commitment

\begin{tabular}{|c|c|c|c|}
\hline Effect & Coefficient & z-value & $P(>|z|)$ \\
\hline $\begin{array}{l}\text { Talent Management } \rightarrow \text { Organizational } \\
\text { Commitment } \rightarrow \text { Employee Performance }\end{array}$ & 0.157 & 2.945 & 0.003 \\
\hline
\end{tabular}

Hypothesis testing result shows that the indirect effect of talent management on employee performance through organizational commitment has a p-value less than 0.050 so that the null hypothesis is rejected, which means that there is an indirect influence of talent management variables on employee performance through organizational commitment. Thus, it can be concluded that the variable organizational commitment is a mediating variable for talent management variable.

\section{CONCLUSION}

The results of the study found that Training Affects Employee Performance, Talent Management Affects Employee Performance, Organizational Commitment Affects Employee Performance, Training Affects Organizational Commitment, Talent Management Affects Organizational Commitment, Training Affects Employee Performance Through Organizational Commitment, and Talent Management Affects Employee Performance Trough Organizational Commitment. The findings also show that organizational commitment serves as a partial mediator. All these findings reinforce previous theories of causality and are combined into one unified model as a model for improving employee performance for construction companies located in Banda Aceh. By increasing training and talent management, it is proven that it can improve organizational commitment and employee performance. Future researchers are expected to develop this tested model by adding research variables such as human capital and company performance.

For practitioners, the model tested can be a reference to improve their company employee performance, especially for the research object that is the construction companies in Banda Aceh City. Some suggestions are provided for this research object.

1. Construction service companies in the city of Banda Aceh are expected to be able to carry out continuous and structured training to improve employee performance. Training must be able to develop employees who have high competency, a work ethic that supports the improvement of company performance.

2. In implementing talent management, construction service companies must be able to carry outa good process from the recruitment process to the placement process. Evaluation of the prospective employee's curriculum vitae is an important part of the process and the employee training process is also a part that cannot be ignored.

3. Work commitment must always be improved by increasing employee pride through increasing the company's concern for its employees.

4. The ability of employees to complete work following the specified quantity and quality is an indicator of the positive performance of employees. For this reason, the construction service company must be able to properly facilitate the achievement of the work targets of its employees. 


\section{International Journal of Business Management and Economic Review}

Vol. 4, No. 02; 2021

ISSN: 2581-4664

\section{REFERENCES}

Alqudah, H. M., Osman, A., \& Alquda, H. (2014). The Effect Of Human Resources Management Practices On Employee Performance. International Journal of Scientific \& Technology Research, 3(9), 129-134.

Angle, H. L., \& Perry, J. L. (1981). An Empirical Assessment of Organizational Commitment and Organizational Effectiveness. Administrative Science Quarterly, 26(1), 1-14.

Azis, N., Djalil, M. A., Bahri, S., \& Sunar. (2017). Commitment And Performance Of Organization Of Harbor Master Office And Port Authority Of Malahayati Port, Banda Aceh, Indonesia. International Journal of Social Science \& Economic Research, 2(10), 5014-5023.

Barkhuizen, E. N., Mogwere, P., \& Schutte, N. (2014). Talent Management, Work Engagement and Service Quality Orientation of Support Staff in a Higher Education Institution. Mediterranean Journal of Social Sciences, 5(4), 69-77. https://doi.org/10.5901/mjss.2014.v5n4p69

Chairy. (2011). Pengaruh Karakteristik Entrepreneurial, Jenis Etnis, Jenis Kelamin dan Profesi Orang Tua Terhadap Intensi Berwirausaha Mahasiswa. Jurnal Manajemen Bisnis, 1(2), 245259.

Coryanata, I. (2014). Pelimpahan Wewenang dan Komitmen organisasi Dalam Hubungan Antara Partisipasi Penyusunan Anggaran dan Kinerja Managerial. Makalah Simposium Nasional Akuntansi (SNA) VII.

Hair, J. F., Hult, G. T. M., Ringle, C., \& Sarstedt, M. (2016). A Primer on Partial Least Squares Structural Equation Modeling (PLS-SEM) (2nd ed.). New York: SAGE Publications, Inc.

Hasibuan, M. S. (2016). Buku Manajemen Sumber Daya Manusia (Revisi). Jakarta: Bumi Aksara.

Hernaus, T., Bach, M. P., \& Vuksic, V. B. (2012). Influence of strategic approach to BPM on financial and non-financial performance. Baltic Journal of Management, 7(4), 376-396. https://doi.org/10.1108/17465261211272148

Kusumawardhani, P. S. (2010). Hubungan Komitmen Terhadap Organisasi Dengan Organizational Citizenship Behavior (OCB) Pada Pegawai Negeri Sipil Di Biro Organisasi Dan Kepegawaian Setda Provinsi Jawa Tengah. Katolik Soegijapranata University.

Luthans, F. (2006). Perilaku Organisasi (Edisi 10).(v. A. Yuwono, S. Purwanti, TA P, \& W. Rosari, Trans.) Yogyakarta: ANDI.

Mangkunegara, A. P. (2013). Manajemen Sumber Daya Manusia Perusahaan. Bandung: Remaja Rosdakarya.

Mathis, R. L., \& Jackson, J. H. (2019). Human Resource Management: Personnel Human Resource Management (Ed. 15). USA: Harvard Business Review.

Meyer, J. P., \& Allen, N. J. (2004). TCM Employee Commitment Survey Academic Users Guide. University of Western Ontario.

Mowday, R. T., Porter, L. W., \& Steers, R. M. (2013). Employee-organization linkages: The psychology of commitment, absenteeism, and turnover. Retrieved from https://books.google.co.id/books?hl=en\&lr=\&id=f_FFBQAAQBAJ\&oi=fnd\&pg=PP1\&dq= The+Psychology+of+Commitment,+Absenteeism,+and+Turnover\&ots=GjRzL7Mg_3\&sig $=\operatorname{Rr9BvXL6mJBF4VJc8x9PBPay6ZY\& redir} \_$esc $=\mathrm{y} \# \mathrm{v}=$ onepage $\& \mathrm{q}=$ The Psychology of Commitment $\% 2 \mathrm{C}$ Absenteeism\%2C and $\mathrm{T}$

Mowday, R. T., Steers, R. M., \& Porter, L. W. (1979). The measurement of organizational 


\section{International Journal of Business Management and Economic Review}

Vol. 4, No. 02; 2021

ISSN: 2581-4664

commitment. Journal of Vocational Behavior, 14(2), 224-247. https://doi.org/https://doi.org/10.1016/0001-8791(79)90072-1

Munandar, A., Musnadi, S., \& Sulaiman, S. (2019). The Effect of Work Stress, Work Load and Work Environment on Job Satisfaction And It's Implication on The Employee Performance of Aceh Investment And One Stop Services Agency. International Graduate Conference (IGC), (Oktober). https://doi.org/10.4108/eai.3-10-2018.2284357

Notoatmojo, S. (2012). Metodologi penelitian Kesehatan (Revisi). Jakarta: Rineka Cipta.

Pella, D. A., \& Inayati, A. (2011). alent Management: Mengembangkan SDM untuk Mencapai Pertumbuhan dan Kinerja Prima. Jakarta: Gramedia Pustaka utama.

Riduwan, \& Kuncoro, E. A. (2014). Cara Menggunakan dan Memaknai Analisis Jalur (Path Analysis) (Cet. 6). Bandung: Alfabeta.

Robbins, S. P., \& Judge, T. A. (2012). Organizational Behavior (15th ed.; S. Yagan, Ed.). San Diego: Pearson.

Smith, C. A., Organ, D. W., \& Near, J. P. (1983). Organizational citizenship behavior: it's nature and antecedents. Journal of Applied Psychology, 68(4), 653-663. https://doi.org/10.1037/0021-9010.68.4.653

Tangkilisan, H. N. S. (2005). Manajemen publik. Jakarta: Gramedia.

Yarnall, J. (2011). Maximising the effectiveness of talent pools: a review of case study literature. Leadership \& Organization Development Journal, 32(5), 510-526. https://doi.org/https://doi.org/10.1108/01437731111146596

Yunus, M., Iis, E. Y., Adam, M., \& Sofyan, H. (2020). Does Motivation Mediate the Effects of Employee Staff Empowerment, Talent, Working Environment, and Career Development on Staff Performance? Quality Management, 21(175), 91-96. 